\title{
Study on the Customer Loyalty of Chinese Commercial Banks
}

\author{
Hua Xin \& Chaozhong Guo \\ School of Business, Beijing Technology and Business University \\ Beijing 100048, China \\ E-mail: xhbtbu@hotmail.com
}

\begin{abstract}
Based on relative researches about customer loyalty, the empirical research method is used to analyze the customer loyalty of Chinese commercial banks, and corresponding measures to enhance the customer loyalty of Chinese commercial banks are proposed according to relative analysis in the article.
\end{abstract}

Keywords: Commercial banks, Customer loyalty, Enhancement measures

As everyone knows, with the opening of the bank industry of China since 2006, the system structure and the market competition situation of Chinese bank industry has greatly changed, and the market competition has turned white hot, and the phenomenon of product homogeneity is variously serious, and the traditional bank quality management has gradually lost the competitive advantage. Various banks increasingly pay attention to the customer relationship management, and they turn the emphases of marketing from the "product-oriented" trading marketing to the "customer-oriented" trading marketing in order to establish stable and long-term cooperation relationship with customers, but some reports also show that the large gap of customer loyalty still exists between Chinese commercial banks with foreign commercial banks, and the proportion of customers who not only satisfy but also are loyalty with banks is very small. Based on that, the empirical method of small samples is used to study the customer loyalty of Chinese commercial banks, and corresponding enhancement measures are proposed in this article.

\section{Research Method and Sample Acquirement}

\subsection{Theoretical base of research}

Based on empirical researches, Germle \& Borwn (1996) put forward that the customer loyalty meant customers' repeated purchase behavior for special service supplier, and their active attitude tendency to the supplier, and the tendency when the demand of this service increased, customers continually took this service supplier as the unique selection object. And according to the degree of customer loyalty, the customer loyalty can be divided into three different layers such as behavior loyalty, intention loyalty and emotion loyalty. Where, behavior loyalty is customers' actual repeated purchase behavior, and it emphasizes the repeated purchase. Intention loyalty includes customers' possible purchase intention, price tolerance and recommendation possibility in the future. Emotion loyalty is customers' attitude to enterprises and their products including accepting the face of product, actively propagandizing and recommending the products of the enterprise, and firstly considering and purchasing these products. Based on Germle \& Borwn (1996)'s subsection of customer loyalty, Zhu Ailing (2007) established the customer loyalty evaluation index system based on empirical researches in her article of "The Evaluation System of Customer Loyalty Degree", which has important instruction function for the customer loyalty of Chinese commercial banks.

\subsection{Sample collection}

Based on above theoretical guidance, to evaluate the customer loyalty of commercial banks and know the customer loyalty of Chinese commercial banks and offer empirical and theoretical reference to enhance the customer loyalty of Chinese commercial banks, the customers of Chinese commercial banks are surveyed by the mode of questionnaire. And 560 effective questionnaires are returned in 600 questionnaires in this survey.

\section{Analysis of Customer Loyalty of Chinese Commercial Banks}

By cleaning up effective questionnaires and analyzing the validity and reliability of various indexes and data in the questionnaires, the result shows that the validity of questionnaires designed in this article is very high, and the interior integer, the reliability and the authenticity of the questionnaires are very high, and the questionnaires could truly reflect customers' evaluations to the bank products and services. Based on survey data, the customer loyalty of Chinese commercial banks will be analyzed as follows. 


\subsection{Customer loyalty analysis of different sorts of consumers}

In the data of Table 1, for the sex, male customers' behavior loyalty, intention loyalty and emotion loyalty are all higher than female customers' a little, and for the marriage, married customers' behavior loyalty is a little lower than unmarried customers', but married customers' intention loyalty and emotion loyalty are higher than unmarried customers', and the married customers' intention loyalty has achieved $33 \%$, and for the educational background, customer loyalty has not obvious proportional relationship with the educated level, and the customers' emotion loyalty with the educational background of junior college has achieved 38\%. For the family income level, customers' behavior loyalties on different levels have few difference, but the proportion of customers' emotion loyalty with above 7500 Yuan of per capital family income is relatively high, and achieves $45 \%$, and at the same time, the customers' intention loyalty and emotion loyalty increases with the increase of per capital family income. By analyzing the total samples, in the various consumers, the proportions of customers in Chinese commercial banks are less and less from behavior loyalty to intention loyalty and then to emotion loyalty. Where, the proportion of customers' behavior loyalty is higher, and exceeds $80 \%$ and the proportion of intention loyalty all exceeds $60 \%$, but the proportion of emotion loyalty is only about $20 \%$. The result of data processing basically accords with Germle \& Borwn's layer subsection from shadow to deep.

\subsection{Customer loyalty analysis of patronage because of different factors}

The data in Figure 1 show that in the customers of Chinese commercial banks, the customers who enter into Chinese commercial banks occupy quite proportions because of "near distance" and "appointed card", and these two proportions respectively are $26.1 \%$ and $24.7 \%$, and the second reason is "good service", and the proportion of customers who enter into Chinese commercial banks because of this reason is $15.6 \%$, and the "convenience" is also the important reason, and its proportion is $12.4 \%$.

The data in Figure 2 show that in the customers of Chinese commercial banks, the proportion of customers who enter into banks with behavior loyalty is the highest one because of "high security", "good service" and "brand", and achieves or approaches $100 \%$, and the proportions of intention loyalty and emotion loyalty are all higher than other reasons, especially the proportions of emotion loyalty respectively achieve $50 \%, 40 \%$ and $35 \%$, and the second reason is "special product", and the proportion of emotion loyalty also achieves $30 \%$, and the proportions of customers' behavior loyalty, intention loyalty and emotion loyalty because of "appointed card" are all the lowest proportion, and the next reasons are "near distance" and "many net sites".

\section{Corresponding Measures to Enhance Customer Loyalty for Chinese Commercial Banks}

By analyzing various sorts of customer's customer loyalty, it is obvious that the customer loyalties of different sorts of consumers who enter into banks because of different reasons have different characters, and the proportions of customer loyalty are obviously different, and based on above analysis, the measures enhancing the customer loyalty of Chinese commercial banks are proposed as follows.

\subsection{Fractionize the customer market and make layered marketing}

From above analysis, the customer loyalties of different sorts of customer in Chinese commercial banks have different characters, so in the strategic development of commercial banks, the customer market must be fractionized, and according to different fractionized markets, the layered marketing and the customer database should be established, which can offer different services aiming at different fractionized markets, and effectively enhance the customer satisfaction. At the same time, by continually treating and analyzing database, banks should not only fully know customers' credit status and consuming habits, but also confirm customers' profit contribution, so banks can offer individualized services aiming at different customers, and accordingly consumers' dependence and loyalty for banks will be enhanced.

\subsection{Strengthen the cultural construction of bank service and implement the brand strategy}

Customer loyalty not only is derived from bank products or the demand of service, but has deeply emotional color. Banks are important public service department, and they must pay attention to the management concept of enterprise, employees" behavior mode, and establish the "customer-centric" service concept, but the permanence of the service concept and the service mode needs to depend on long-term edification and ablution of band service cultures. Of course, the establishment of culture is a systematic long-term engineering, and it requires that bank enterprises should always pay attention to establish long-term and interdependent relationship with clients, and build customers' sustainable satisfaction by continual encouragement and durative digging and value transfer. And banks can finally hold customers and implement the customers' emotion loyalty by repeated communication between client and bank.

Brand represents the character, the benefit and the persistent promise of the products offered by the enterprise for customers, and good brand is the guarantee of good quality. Above data also show that brand has important function for the customer loyalty of commercial banks. As the public service enterprise, commercial banks should not only ensure customers' benefit, scrupulously abide by credit and establish the brand of enterprise, but also pay attention to the client 
relationship management, implement the individualized character service, give prominence to the character of products, offer high cost performance and good-quality band products to customers, and accordingly realize brand loyalty. At present, the large gap still exists in the brand construction between Chinese commercial banks and international commercial banks, and the branding strategy needs to be realized for a long term.

\subsection{Enhance the innovation ability of bank products and give prominence to the characters of products}

Because the bank products are very easy to be simulated, the similitude degree of the products of Chinese commercial banks is very high, and the homogeneity phenomenon is very serious, and the core competitive ability of commercial banks is not product, but the more important ability is the innovation ability of product and service. Based on the subsection of the bank customer market, banks should exactly grasp clients' demand and market development tendency, design financial products, and satisfy the demands of various subsection market by diversified and individualized products, and hold customers by special products, and accordingly enhance the customer loyalty of banks.

\subsection{Enhance the quality of bank service and provide band products with high cost performance}

As service enterprises, banks can not have customer loyalty without the guarantee of service quality. Good service is the essential to attract and hold customers. When the market competition is not so drastic, banks can hold numbers of customers only by various conversion costs not by high-quality services, but most of these customers may only have behavior loyalty, not intention loyalty or emotion loyalty. After the bank industry of China opened to the outside world in 2006, the competition of Chinese commercial banks is increasingly drastic, and customers' conversion costs reduce, and their conversion benefits increase, which induce many customers flow away, so it is very important to enhance customer loyalty, and good-quality service is one important measure to hold customers for long for banks. To enhance the service quality, banks should first satisfy customers' demand, so Chinese commercial banks should consider customers' demand in various parts of the service product, and regard customers as the "god" of the bank. Under the premise of guaranteeing good-quality service, Chinese commercial banks should also reduce customers' costs, save money cost, time cost and psychology cost by various methods such as simplifying service flow, reducing charge, and increasing the added value of product, which is extremely important to enhance customer loyalty for Chinese commercial banks.

\subsection{Utilize the conversion barrier reasonably}

To utilize the conversion barrier of Chinese bank industry reasonably could increase customers' conversion cost, prevent customer flow and enhance customers' behavior loyalty to some extent. It is not the final target to enhance customers' behavior loyalty by the conversion barrier, and the final target should convert customers' behavior loyalty into intention loyalty even emotion loyalty by measures such as enhancing the service quality, and accordingly hold customers for a long time.

\subsection{Establish the customer communication platform and high-effective emergency disposal mechanism}

For any enterprise, customers' demand is very important, so are Chinese commercial banks. To establish the platform of effective communication with customers and fully grasp customers' demand and demand trends, banks should not only offer the products or services with more pertinence, but also fully respect customers, and keep the interaction with customers, which are the important measures to enhance customers' emotion loyalty. High-efficiency emergency disposal mechanism is the key for successful modern enterprises, and banks are service enterprises, and customer complaints are inevitable. By providing high-level compensation service for customers in the shortest time, banks could acquire customers' favors and trusts, increase customer loyalty, carefully consider and analyze the causes of customer complaints, and perfect the products and services by continually improving and optimizing services in the shortest time.

\section{References}

Gremler, D. D., \& Brown. (1996). Service Loyalty: Its Natural Impotence and Implications, Advancing Service Quality. A Global Perspective, 1996.

Hu, Yuhui. (2006). The Improvement of Customer Loyalty in Commercial Banks. Commercial Research, No.6.

Lei, Dazhang. (2005). Study on the Management of Customer Loyalty. Modernization of Management, No.5.

Sun, Yanfeng. (2007). Influencing Factors and Countermeasures of Customer Loyalty for Commercial Banks. Northern Economy, No.12.

Zhao, Kai, Li, Yanjun \& Lin, Zhijian. (2007). Analysis on Customer Loyalty of Commercial Banks. Communication of Finance and Accounting, No.3.

Zhu, Ailing. (2007). Study on the Comprehensive Evaluation System of Customer Loyalty. Master's Degree Thesis of Tianjin University. Dec of 2007. 
Table 1. Statistics of customer loyalty of different sorts of consumer (\%)

\begin{tabular}{|c|c|c|c|c|c|c|c|c|c|c|c|c|c|c|c|}
\hline & \multicolumn{2}{|c|}{ Sex } & \multicolumn{2}{|c|}{ Marriage } & \multicolumn{5}{|c|}{ Educated experience } & \multicolumn{6}{|c|}{ Family per capita income (Yuan) } \\
\hline & Male & $\begin{array}{c}\text { Fem } \\
\text { ale }\end{array}$ & $\begin{array}{c}\text { Marrie } \\
\mathrm{d}\end{array}$ & $\begin{array}{c}\text { Un } \\
\text { married }\end{array}$ & \begin{tabular}{|c} 
Junior \\
high \\
school \\
and \\
below it
\end{tabular} & $\begin{array}{c}\text { Senior } \\
\text { high } \\
\text { school }\end{array}$ & $\begin{array}{l}\text { Junior } \\
\text { college }\end{array}$ & $\begin{array}{l}\text { Under } \\
\text { graduate }\end{array}$ & $\begin{array}{c}\text { Post- } \\
\text { Under } \\
\text { graduate }\end{array}$ & $\frac{v}{\grave{g}}$ & $\begin{array}{l}\bar{y} \\
\stackrel{0}{0} \\
\dot{\omega} \\
\stackrel{8}{8}\end{array}$ & 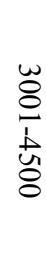 & $\begin{array}{l}\text { 竞 } \\
\frac{1}{\grave{g}} \\
\stackrel{8}{8}\end{array}$ & $\begin{array}{l}\stackrel{8}{8} \\
\frac{1}{1} \\
\frac{1}{8}\end{array}$ & $\begin{array}{c}\text { Above } \\
7501\end{array}$ \\
\hline $\begin{array}{l}\text { Behavio } \\
\text { r loyalty }\end{array}$ & 86 & 85 & 82 & 86 & 100 & 88 & 87 & 86 & 84 & 84 & 84 & 91 & 80 & 88 & 83 \\
\hline $\begin{array}{c}\text { Intentio } \\
\mathrm{n} \\
\text { loyalty }\end{array}$ & 65 & 60 & 66 & 62 & 50 & 67 & 59 & 62 & 68 & 60 & 61 & 66 & 66 & 68 & 63 \\
\hline $\begin{array}{c}\text { Emotio } \\
\mathrm{n} \\
\text { loyalty }\end{array}$ & 17 & 15 & 33 & 19 & 10 & 22 & 38 & 19 & 17 & 16 & 22 & 23 & 42 & 28 & 45 \\
\hline
\end{tabular}

Table 2. Statistics of customer loyalty of patronage because of different factors ( $\%)$

\begin{tabular}{|c|c|c|c|c|c|c|c|c|c|}
\hline & $\begin{array}{c}\text { Close } \\
\text { distance }\end{array}$ & $\begin{array}{c}\text { Appointed } \\
\text { card }\end{array}$ & Convenience & $\begin{array}{c}\text { Good } \\
\text { service }\end{array}$ & $\begin{array}{c}\text { High } \\
\text { security }\end{array}$ & Brand & $\begin{array}{c}\text { Many } \\
\text { net } \\
\text { sites }\end{array}$ & $\begin{array}{c}\text { Special } \\
\text { product }\end{array}$ & Others \\
\hline $\begin{array}{c}\text { Behavior } \\
\text { loyalty }\end{array}$ & 80 & 80 & 87 & 98 & 100 & 96 & 86 & 88 & 92 \\
\hline $\begin{array}{c}\text { Intention } \\
\text { loyalty }\end{array}$ & 60 & 56 & 66 & 75 & 82 & 74 & 69 & 73 & 73 \\
\hline $\begin{array}{c}\text { Emotion } \\
\text { loyalty }\end{array}$ & 17 & 14 & 23 & 40 & 50 & 35 & 18 & 30 & 25 \\
\hline
\end{tabular}

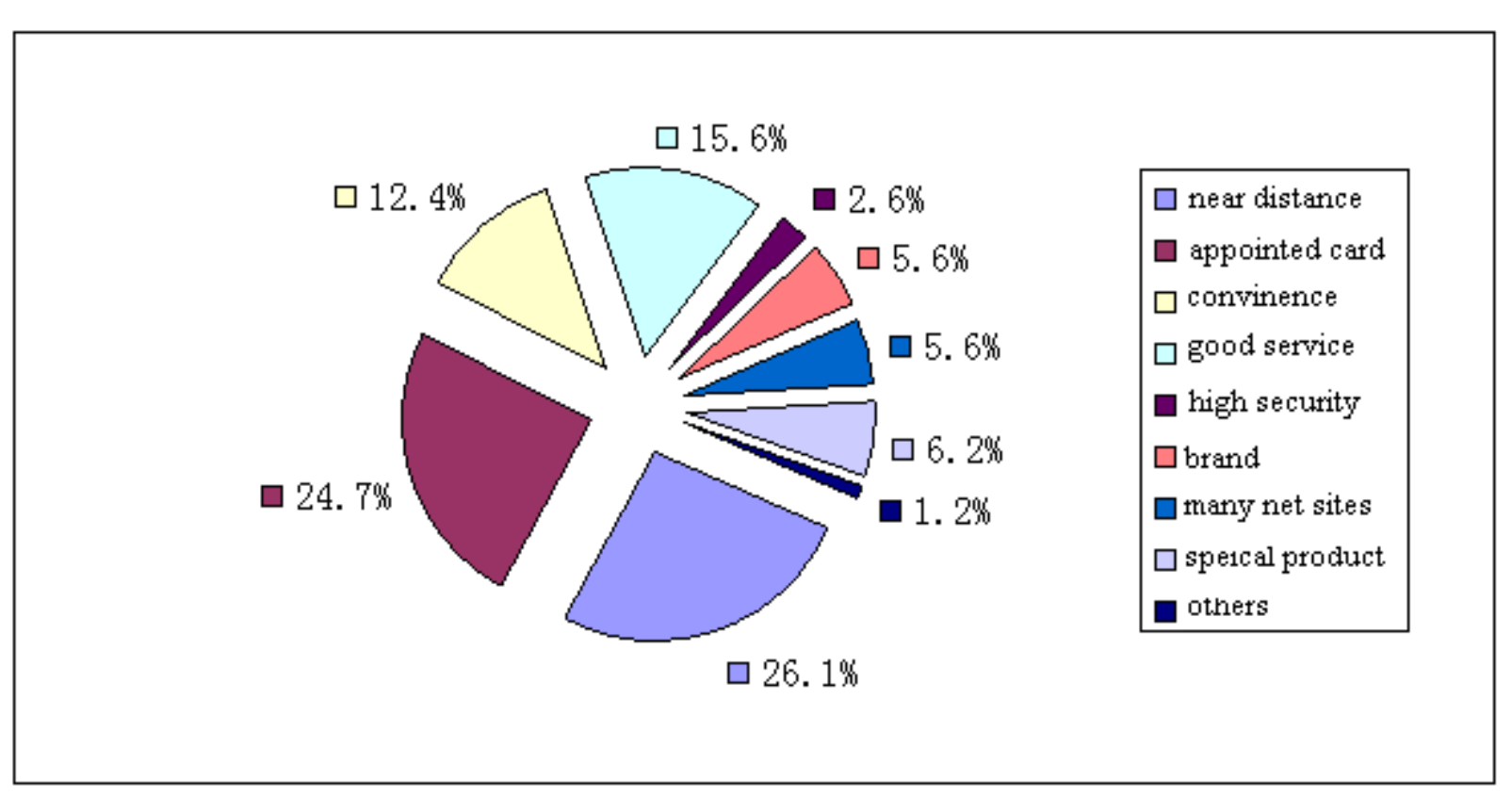

Figure 1. Statistics of the patronage causes for banks 